\title{
Effect of processing conditions on characteristics of dehydrated bee-pollen and correlation between quality parameters
}

\author{
Adriane Alexandre Machado De-Melo ${ }^{\text {a, }}$, , Maria Leticia Miranda Fernandes Estevinho ${ }^{b}$, \\ José Augusto Gasparotto Sattler ${ }^{a}$, Bianca Rodrigues Souza ${ }^{a}$, Alex da Silva Freitas ${ }^{c}$, \\ Ortrud Monika Barth ${ }^{\mathrm{d}}$, Ligia Bicudo Almeida-Muradian ${ }^{a}$ \\ a Laboratory of Food Analysis, Department of Food and Experimental Nutrition, Pharmaceutical Sciences School, University of São Paulo, São Paulo, SP, Brazil \\ ${ }^{\mathrm{b}}$ CIMO-Mountain Research Center, Department of Biology and Biotechnology, Polytechnic Institute of Bragança, Bragança, Portugal \\ c Laboratory of Marine Geology, Federal Fluminense University, Niterói, RJ, Brazil \\ d Laboratory of Palynology, Department of Geology, Institute of Geosciences, Federal University of Rio de Janeiro, Rio de Janeiro, RJ, Brazil
}

\section{A R T I C L E I N F O}

\section{Article history:}

Received 11 May 2015

Received in revised form

2 September 2015

Accepted 6 September 2015

Available online 9 September 2015

\section{Keywords:}

Dehydration methods

Bee products

Nutritional value

Biological properties

Microbiological quality

Chemical compounds studied in this article:

$\alpha$-Tocopherol (PubChem CID: 14985)

Thiamine (PubChem CID: 1130)

Riboflavin (PubChem CID: 493570)

Iron (PubChem CID: 23925)

Copper (PubChem CID: 23978)

Zinc (PubChem CID: 23994)

Magnesium (PubChem CID: 5462224)

$\mathrm{DPPH}$

Free radical (PubChem CID: 2735032)

\begin{abstract}
A B S T R A C T
The aim of the present study was to compare the physical, chemical and biological parameters and the microbiological quality of bee-pollen samples treated with different dehydration processes and to correlate the results. The samples came mainly from Eucalyptus (Myrtaceae) and Eupatorium (Asteraceae) plants. The dehydration conditions of the samples influenced the $L^{*} \mathrm{a}^{*} \mathrm{~b}^{*}$ colour parameters and the biological value. Unlike the protein and lipid content, the glucose and fructose content were unaffected. The vitamin E content $(27.2 \pm 0.3 \mu \mathrm{g} / \mathrm{g}, 27.5 \pm 0.4 \mu \mathrm{g} / \mathrm{g})$ in oven-dehydrated samples with forced air circulation was significantly lower $(\mathrm{P}<0.05)$ compared with lyophilized samples $(37.5 \pm 0.2 \mathrm{~g} / 100 \mathrm{~g}$, $53.7 \pm 3.9 \mathrm{~g} / 100 \mathrm{~g})$. Overall, the results were inconclusive for vitamin B complex, minerals and microbiological indicators. There was a positive correlation between the colour parameters $\mathrm{L}^{*}$ and $\mathrm{b}^{*}$ and the total phenolic content, as well as between phenolic content and the antioxidant and antimicrobial capacity. The data indicate that lyophilization might be a viable alternative to the current process, resulting in dehydrated bee-pollen with higher biological activity.
\end{abstract}

() 2015 Elsevier Ltd. All rights reserved.

\section{Introduction}

Bee-pollen results from the agglutination of hundreds of pollen grains collected from flowers by bees. The bees add small amounts of salivary secretions, nectar and/or honey to the pollen grains

\footnotetext{
* Corresponding author. Laboratório de Análise de Alimentos da Faculdade de Ciências Farmacêuticas da USP, Avenida Professor Lineu Prestes, 580, Bloco 13-A, CEP: 05580-000, Cidade Universitária, São Paulo, SP, Brazil.

E-mail addresses: adriane.melo@usp.br (A.A.M. De-Melo), leticia@ipb.pt (M.L.M.F. Estevinho), jagasparotto@gmail.com (J.A.G. Sattler), bianca.alimentos@ gmail.com (B.R. Souza), alexsilfre@gmail.com (A.S. Freitas), monikabarth@gmail. com (O.M. Barth), ligiabi@usp.br (L.B. Almeida-Muradian).
}

(Brasil, 2001; Campos et al., 2008). Bee-pollen contains different amounts of reducing and non-reducing sugars (Qian, Khan, Watson, \& Fearnley, 2008), fibres (Funari et al., 2003), essential aminoacids (Paramás, Bárez, Marcos, García-Villanova, \& Sánchez, 2006), saturated and unsaturated fatty acids (Human \& Nicolson, 2006; Yang et al., 2013), minerals (Morgano et al., 2012; Yang et al., 2013), vitamins (Arruda, Santos-Pereira, Freitas, Barth, \& Almeida-Muradian, 2013; Melo \& Almeida-Muradian, 2010; Oliveira et al., 2009) and bioactive metabolites such as phenolic compounds (Carpes et al., 2008). Pharmacological properties are attributed to the phenolics, such as antimicrobial, antioxidant, antiinflammatory, antimutagenic, hepatoprotective and antiallergenic properties (Campos et al., 2008; Medeiros et al., 2008; Nogueira, 
Iglesias, Feás, \& Estevinho, 2012; Pascoal, Rodrigues, Teixeira, Feás, \& Estevinho, 2014).

The beekeepers collect bee-pollen from the hives and transport it to the processing unit. Generally, processing involves cleaning, freezing, thawing, dehydration, packaging, transportation and marketing. The purpose of the dehydration process is to increase the product shelf life. In nature, bee-pollen contains $20-30 \mathrm{~g} / 100 \mathrm{~g}$ of water (moisture) and has a water activity from 0.66 to 0.82 , which provides a favourable matrix for the proliferation of microorganisms and possible chemical and enzymatic reactions (Campos et al., 2008; Franco \& Landgraf, 2009; Rocha, 2013). Once dehydrated, the bee-pollen is designated as "dehydrated bee-pollen", for which Brazilian legislation establishes a maximum temperature of $42{ }^{\circ} \mathrm{C}$ for the process (Barreto, Funari, \& Orsi, 2005; Brasil, 2001). The use of an electric oven for dehydrating bee-pollen might be related to equipment costs, since other efficient conservation alternatives such as lyophilization are scarcely used. Because the results of dehydration conditions on the quality of bee-pollen are poorly understood, the purpose of this study was to compare the use of an electric oven with forced air circulation and a lyophilizer on the physical, chemical, biological and microbiological quality of dehydrated bee-pollen produced in Brazil, as well to correlate the results.

\section{Material and methods}

\subsection{Bee-pollen samples}

Bee-pollen samples produced by Apis mellifera were collected from an apiary in São Paulo, Brazil, in April/2012 and September/ 2012. Pollen analysis of the bee-pollen collected in April indicated the predominance of Eucalyptus with some Asteraceae/Linguliflora and Mimosa caesalpiniaefolia. In the bee-pollen collected in September, the genus Eupatorium was predominant, with a lesser content of Piper, Elephantopus, Eucalyptus, Cyperaceae and Anacardiaceae. The pollen analysis was performed according to the method described by Barth et al. (2010). After collection, the product was frozen at $-20^{\circ} \mathrm{C}$ in the apiary then sent to the MN Própolis (Mogi das Cruzes, São Paulo, Brazil), a food company that commercialize bee-pollen dehydrated in electric oven with forced air circulation and recently implemented the process of dehydration by lyophilization. Each sample was divided into two aliquots and processed under the conditions adopted by the company. One aliquot was frozen at $-40{ }^{\circ} \mathrm{C}$ then dehydrated in a vacuum lyophilizer (FD-TFD-80LF4, Edwards) for $18 \mathrm{~h}$. The other aliquot was thawed at room temperature and dried in an electric oven with forced air circulation (ESA 1368 , Sercon) at $42^{\circ} \mathrm{C}$ for $24-52 \mathrm{~h}$. For the oven drying, the variation in processing time occurred because the trays were removed when the moisture in the product reached a value close to that observed in the sample subjected to lyophilization (6-8 g/100 g). The samples were vacuum packed in food-grade polyethylene bags, then sent to the Laboratory of Food Analysis of the Pharmaceutical Science School, University of São Paulo, São Paulo, Brazil, where they were stored at room temperature and away from light for 30 days. Part of the experiment was conducted in the Laboratory of Microbiology of the Agrarian School, Polytechnic Institute of Bragança, Bragança, Portugal. Immediately before each analysis, the samples were crushed and sieved through a $0.595-\mathrm{mm}$ sieve.

\subsection{Total nitrogen - protein content}

The total nitrogen content was determined by micro-Kjeldahl method from $100 \mathrm{mg}$ of sample. A factor of 6.25 was used to convert nitrogen to crude protein (Almeida-Muradian, Arruda, \& Barreto, 2012; AOAC, 2000).

\subsection{Ethereal extract - lipid content}

Lipid content was determined according to the Soxhlet intermittent method (Almeida-Muradian et al., 2012), based on lipid extraction by diethyl ether from $2 \mathrm{~g}$ of material.

\subsection{Glucose and fructose determination}

The extraction and determination of the sugars glucose and fructose were performed using the method described by AlmeidaMuradian et al. (2012) with a high performance liquid chromatography system (Shimadzu, Software LC Solution V.1.25 SP2) composed of a pump (LC-20AT), an auto sampler and a fluorescence detector (RF$10 \mathrm{AXL})$. The separation occurred in a mobile phase composed of acetonitrile and water $(85: 15, \mathrm{~mL}: \mathrm{mL})$ at a flow rate of $1 \mathrm{~mL} / \mathrm{min}$, with a $20 \mu \mathrm{L}$ injection volume into a $\mathrm{NH}_{2}$ normal phase column [Shim-pack (CLC-Sil), $5 \mu \mathrm{m}, 25 \mathrm{~cm} \times 4.6 \mathrm{~mm}$, guard column $10 \mathrm{~cm} \times 4.6 \mathrm{~mm}$ ]. Refractive index detection was used. The column temperature was maintained at $40{ }^{\circ} \mathrm{C}$. Quantification was performed by external standard curve using at least five concentration levels for each standard.

\subsection{Determination of minerals}

Minerals were extracted by acid digestion (nitric acid and perchloric acid, 2:1, mL: $\mathrm{mL}$ ) in an open system from $500 \mathrm{mg}$ of sample (Malavolta, Vitti, \& Oliveira, 1989). The sodium (Na), calcium $(\mathrm{Ca})$, potassium $(\mathrm{K})$, copper $(\mathrm{Cu})$, magnesium $(\mathrm{Mg})$ and zinc (Zn) concentrations were determined by inductively coupled plasma optical emission spectrometry (ICP-OES) (Ciros Vision EOP, Spectro) as described by Morgano et al. (2012), with the following operating parameters: forward power of $1.45 \mathrm{~kW}$; cooling air flow rate of $12 \mathrm{~L} / \mathrm{min}$; auxiliary argon flow of $1 \mathrm{~L} / \mathrm{min}$; nebulizer air flow rate of $1 \mathrm{~L} / \mathrm{min}$ and sample flow rate of $2 \mathrm{~mL} / \mathrm{min}$. The wavelengths were specific for each element and a calibration curve was prepared with different concentrations of each mineral.

\subsection{Determination of vitamin $E$}

The determination of $\alpha$-tocopherol (vitamin E) was performed as described by Melo and Almeida-Muradian (2010) using a high performance liquid chromatography system (Shimadzu, Software LC Solution V.1.25 SP2) composed of a pump (LC-20AT), an auto sampler and a fluorescence detector (RF-10AXL) with a $295 \mathrm{~nm}$ excitation wavelength and a $330 \mathrm{~nm}$ emission wavelength. A $25 \mathrm{~cm}$ silica Shim-pack CLC-Sil column (Shimadzu) with a pre-filtered and degassed mobile phase consisting of hexane and isopropyl alcohol (99:1, mL: $\mathrm{mL}$ ) and $1.5 \mathrm{~mL} / \mathrm{min}$ flow rate was used. The $\alpha$-tocopherol was identified by comparison of the retention time of the standard synthetic $\alpha$-tocopherol and quantified using an external standard curve of at least five concentration levels.

\subsection{Determination of $B$ complex vitamin}

Arruda et al. (2013) validated methods for the extraction and identification of vitamin B complex vitamins in bee-pollen. These methods, operating parameters and the same equipment were used to determine the values of thiamine (vitamin $B_{1}$ ), riboflavin (vitamin $\mathrm{B}_{2}$ ), niacin and niacinamide (vitamin PP or $\mathrm{B}_{3}$ ), pyridoxamine, pyridoxal and pyridoxol (vitamin $\mathrm{B}_{6}$ ).

\subsection{Ethanolic extracts (ETE)}

Ethanolic extracts (ETE) were prepared as described by Carpes et al. (2008), with modifications. The compounds were extracted from a $2 \mathrm{~g}$ sample with $25 \mathrm{~mL}$ of ethanol solution (ethanol: distilled 
water, 70:30, $\mathrm{mL}: \mathrm{mL}$ ) in a water bath at $70{ }^{\circ} \mathrm{C}$ for 30 min with $105 \mathrm{rpm}$ agitation. The extract was filtered by a quality filter (porosity: 3 microns) into a $25 \mathrm{~mL}$ volumetric flask and the volume was adjusted with ethanol solution (ethanol: distilled water, 70:30, $\mathrm{mL}: \mathrm{mL})$, then stored in amber glass at $-4{ }^{\circ} \mathrm{C}$ until analysed. All extractions were performed in triplicate.

\subsection{Total phenolic content}

The total phenolic content was determined as described by Carpes et al. (2008), with the following modifications: the ETE was diluted in ethanol solution (ethanol:distilled water, 70:30, $\mathrm{mL}: \mathrm{mL}$ ) rather than water and all readings were performed with a spectrophotometer operating at $20^{\circ} \mathrm{C}$. A gallic acid standard curve was constructed and the results were expressed in $\mathrm{mg}$ of gallic acid equivalents (GAE) per $g$ of dehydrated bee-pollen.

\subsection{Antioxidant capacity}

Two methods were used to determine the antioxidant capacity of the samples: 1,1-diphenyl-2-picrylhydrazyl (DPPH) method and oxygen radical absorbance capacity (ORAC) assay. In the DPPH method is measured the reduction of this radical by receiving an electron or a hydrogen atom from antioxidant. The ORAC assay indicate the radical scavenging ability of antioxidant against peroxyl radical generated from 2,2'-azobis(2-aminopropane) dihydrochloride (AAPH).

\subsubsection{DPPH method}

The antioxidant capacity of the samples was determined by the DPPH method according to the procedure described by BrandWilliams, Cuvelier, and Berset (1995), with modifications. An aliquot of $1.5 \mathrm{~mL}$ of a methanol solution of DPPH• (with an absorbance at $517 \mathrm{~nm}$ between 0.600 and 0.700 ) was added to a test tube containing $0.5 \mathrm{~mL}$ of ETE diluted in ethanol solution (ethanol: distilled water, 70:30, mL: $\mathrm{mL}$ ). The tubes were incubated at room temperature away from light for $30 \mathrm{~min}$, and then read in a spectrophotometer (UV 1650 PC, Shimadzu) at an absorbance of $517 \mathrm{~nm}$ at $20{ }^{\circ} \mathrm{C}$. Different solutions were made from each ETE, and the percentage discoloration (PD) was calculated according to the formula proposed by Mensor et al. (2001):

Solutions of Trolox ${ }^{\circledR}$ at concentrations of $6.25 ; 12.5 ; 25 ; 50 ; 75$ and $100 \mu \mathrm{mol} / \mathrm{L}$ were prepared to construct a standard curve of concentration $x$ PD. The results were expressed in $\mu \mathrm{mol}$ of Trolox ${ }^{\circledR}$ equivalents (TE) per $g$ of dehydrated bee-pollen.

\subsubsection{ORAC method}

The ORAC determination was done by the method described by Ou, Hampsch-Woodill, and Prior (2001) with modifications proposed by Huang, Ou, and Prior (2005). The ETE were diluted in ethanol solution (ethanol: distilled water, 70:30, mL: $\mathrm{mL}$ ) and a $25 \mu \mathrm{L}$ aliquot was analysed with Fluorescein at $40 \times 10^{-9} \mathrm{~mol} / \mathrm{L}, \mathrm{AAPH}$ at $0.153 \mathrm{~mol} / \mathrm{L}$, a plate reader (Synergy HT - Bio Tek Instruments) and working temperature of $37^{\circ} \mathrm{C}$. Solutions of Trolox $\AA$ at concentrations $6.25 ; 12.5 ; 25 ; 50 ; 75$ and $100 \mu \mathrm{mol} / \mathrm{L}$ were prepared to construct a standard curve. The relative value of ORAC was calculated based on a linear regression equation between the concentration of Trolox ${ }^{\circledR}$ and the area under the fluorescence curve automatically generated by the instrument. The results were expressed in $\mu$ mol of Trolox ${ }^{\circledR}$ equivalent (TE) per $g$ of dehydrated bee-pollen.

\subsection{Anti-inflammatory capacity}

The percentage of inhibition of the enzyme hyaluronidase was used as an indirect measurement of the anti-inflammatory capacity of the samples. The methodology described by Silva, Rodrigues, Feás, and Estevinho (2012) was used and methanol extracts was prepared as described by Morais, Moreira, Feás, and Estevinho (2011). Reactions contained $50 \mu \mathrm{L}$ of dehydrated bee-pollen extract and $50 \mu \mathrm{L}$ $\left(5.833 \times 10^{-6} \mathrm{~kat}\right)$ of hyaluronidase (Type IV-S: bovine tests).

\subsection{Antimicrobial capacity}

Antimicrobial capacity of the samples was determined against Gram negative bacteria (Escherichia coli ATCC; E. coli ESA72; Klebsiella ATCC; Klebsiella ESA61), Gram positive bacteria (Streptococcus pyogenes ATCC; S. pyogenes ESA12; Staphylococcus aureus ATCC; S. aureus ESA54) and yeasts (Candida albicans ATCC; C. albicans ESA109). The microorganisms were isolated from biological fluids and identified in the Northeast Hospital Centre, Bragança, Portugal. Bacteria and yeasts were plated on Mueller-Hinton medium with glycerol solution (glycerol: distilled water, 20:80, $\mathrm{mL}: \mathrm{mL}$ ) and stored at $-70{ }^{\circ} \mathrm{C}$. For analysis, the bacteria were plated on nutrient agar $\left(37 \pm 1^{\circ} \mathrm{C}, 24 \mathrm{~h}\right)$ and yeasts on solid Yeast Nitrogen Base medium $\left(25 \pm 1^{\circ} \mathrm{C} ; 48 \mathrm{~h}\right)$. The inoculum was transferred to an Erlenmeyer flask containing a sodium chloride solution $(0.85 \mathrm{~g} / 100 \mathrm{~mL}$ of distilled water) and adjusted to 0.5 on the MacFarland scale as confirmed by a spectrophotometric (Varian UV-Visible Spectrophotometer, Cary 50 Scan) reading at $580 \mathrm{~nm}$ for bacteria and $640 \mathrm{~nm}$ for yeasts. Cell suspensions were finally diluted to $10^{4} \mathrm{CFU} / \mathrm{mL}$ for use in the activity assays. Tests were carried out according to the procedure described by Morais et al. (2011). Fluconazole and gentamycin were used as positive controls. The results were expressed as minimum inhibitory concentration (MIC) which was defined as the lowest concentration of dehydrated bee-pollen extract that inhibited visible growth of microorganisms.

\subsection{Microbiological quality}

Counts of yeasts and molds (IPQ 1985), mesophilic microorganisms (IPQ 2002) and psychrotrophics (IPQ 1987) were made and the results expressed as colony forming units per $\mathrm{g}$ of dehydrated bee-pollen (CFU/g). The enumeration of total coliforms was done with a SimPlate kit (BioControl) (AOAC, 2000) and the results were expressed as the most probable numbers of coliforms per gram of bee-pollen (MPN/g).

\subsection{Lab instrumental colour parameters}

The instrumental colour parameters were determined by reflectance on a ColorQuest XE equipment (Hunterlab, serial number: CQX 2329) operating CIE $L^{*} a^{*} b^{*}\left(L^{*}: 0\right.$ to 100 , a*: - blue to + red, and b*: - green to + yellow) with Universal Software V4.10. Each sample was analysed in a 50-mm quartz cuvette and the results were expressed as $\mathrm{L}^{*} \mathrm{a}^{*} \mathrm{~b}^{*}$ parameters.

\subsection{Statistical analysis}

All analyses were performed in triplicate, and the results were expressed as the mean \pm standard deviation. To identify treatment effects, comparisons were made using the nonparametric Kruskal-Wallis test and the data compared (post hoc) two by two by the non-parametric Mann Whitney test for each variable. The relationship between variables was assessed by Spearman's correlation. All comparisons used a significance level $(\alpha)$ of 0.05 .

\section{Results and discussion}

\subsection{Physicochemical parameters}

The physicochemical parameters of the samples are presented in Table 1. Studies indicate that in the dehydrated bee-pollen the 
protein content can vary from 10 to $45 \mathrm{~g} / 100 \mathrm{~g}$, fructose from 12 to $24 \mathrm{~g} / 100 \mathrm{~g}$, glucose from 7 to $22 \mathrm{~g} / 100 \mathrm{~g}$, lipids from 1 to $13 \mathrm{~g} / 100 \mathrm{~g}$ and ash from 0.5 to $6 \mathrm{~g} / 100 \mathrm{~g}$ (Arruda et al., 2013; Campos et al., 2008; Nogueira et al., 2012; Qian et al., 2008). The lipid and glucose content observed in the samples of this study were consistent with the values cited above. However, the protein content was below $10 \mathrm{~g} / 100 \mathrm{~g}$ and the fructose content was above $24 \mathrm{~g} /$ $100 \mathrm{~g}$ in the samples collected in September, which may be related to botanical origin of the samples (Campos et al., 2008).

No significant differences $(P>0.05)$ were observed for glucose and fructose values between the two processes. These carbohydrates are probably stable under both conditions applied. A significantly lower level $(\mathrm{P}<0.05)$ of proteins in samples dehydrated in electric oven indicates that heating (even at moderate temperatures) and the presence of gases (such as oxygen) can induce loss of these compounds. Significantly higher $(P<0.05)$ lipids were observed in the lyophilized samples. Processing conditions can change the structure of the grains, which may or may not facilitate the extraction of the compounds. Freeze drying seems to facilitate the extraction of bee-pollen lipids when compared with an electric oven with forced air circulation (Domínguez-Valhondo, Gil, Hernández \& González-Gómez, 2011).

In previous studies with dehydrated bee-pollen samples, different amounts of $\mathrm{K}(3.2-20 \mathrm{~g} / \mathrm{kg}), \mathrm{Ca}(0.2-3.5 \mathrm{~g} / \mathrm{kg}), \mathrm{Mg}(0.2-3 \mathrm{~g} /$ $\mathrm{kg}), \mathrm{Na}(1-862 \mathrm{mg} / \mathrm{kg}), \mathrm{Zn}(30-250 \mathrm{mg} / \mathrm{kg})$ and $\mathrm{Cu}(2-20 \mathrm{mg} / \mathrm{kg})$ were observed (Funari et al., 2003; Carpes, Mourão, Alencar, \& Masson, 2009; Bogdanov, 2012; Morgano et al., 2012; Yang et al., 2013). The values observed in this study are consistent with literature, except the potassium content $(2.6 \pm 0.1 \mathrm{~g} / \mathrm{kg})$. The mineral content can vary according to differences on the floral origin of pollen and on the plant growth conditions, such as soil and geographic origin (Carpes et al., 2009). The influence of treatment on Ca, K, Mg, $\mathrm{Na}, \mathrm{Zn}$ and $\mathrm{Cu}$ content was inconclusive. It was identified a positive correlation between $\mathrm{Zn}$ content and the antioxidant capacity $(\mathrm{R}=0.830, \mathrm{P}=0.001)$ and the $\mathrm{Cu}$ content and the antioxidant capacity $(R=0.769, P=0.003)$ for both methods (DPPH and ORAC), however, $\mathrm{Cu}$ and $\mathrm{Zn}$ can not be considered as antioxidants compounds. These minerals are cofactors for copper, zinc superoxide dismutase ( $\mathrm{Cu}-\mathrm{Zn}$ SOD), an important antioxidant enzime already reported in plants (Lee et al., 2007); therefore, $\mathrm{Cu}$ and $\mathrm{Zn}$ might be indicators of presence of the $\mathrm{Cu}-\mathrm{Zn}$ SOD in these bee-pollen samples.

The vitamin $E$ content was lower $(P<0.05)$ in samples dehydrated in an electric oven. According to Miquel, Alegría, Barberá, Farré, and Clemente (2004) factors such as light, oxygen and temperature are responsible for degradation of tocopherols. In Brazil, studies evaluating the presence of $\alpha$-tocopherol in bee-pollen were performed only with samples treated in an oven at $42^{\circ} \mathrm{C}$. Under this condition, the vitamin E content varied from 4.7 to $113.9 \mu \mathrm{g} / \mathrm{g}$ (Melo \& Almeida-Muradian, 2010; Oliveira et al., 2009; Sattler, 2013). Correlation analysis (Spearman) showed that the vitamin E content is strongly $(\mathrm{R}=0.65, \mathrm{P}<0.05)$ associated with the colour parameter $\mathrm{b}^{*}$ (yellow colour) so yellow bee pollen samples could be presumably characterized by the presence of $\alpha$-tocopherol.

Treatment effects on the content of B complex vitamins were inconclusive. Although heating can cause a loss of these vitamins in foods (Sucupira, Xerez, \& Souza, 2012), this was not completely observed in this study. Studies with dehydrated bee-pollen samples indicated variation in the amount of thiamine $(0.5-1.8 \mathrm{mg} / 100 \mathrm{~g})$, riboflavin $(0.4-2.6 \mathrm{mg} / 100 \mathrm{~g})$, niacin $(0.7-3.9 \mathrm{mg} / 100 \mathrm{~g})$, nicotinamide (2.4-10.7 mg/100 g), pyridoxine (0.3-0.9 mg/100 g), pyridoxal (0.1-6.7 mg/100 g) and piridoxol (0.1-0.2 mg/100 g) according to botanical origin of the samples (Arruda et al., 2013; Souza, 2014). The values described in this study are consistent with the literature. It should be noted that a $25 \mathrm{~g}$ sample contains at least $50 \%$ of the recommended daily intake of vitamin $B_{6}(1.3 \mathrm{mg} /$ day, males and females, 31-50 y) (USDA, 1998).

There were variations in the colour parameters $\mathrm{L}^{*}$ and $\mathrm{b}^{*}$ with the processing conditions. The influence of treatment on the parameter $a^{*}$ was observed only in the sample collected in September. The parameter $\mathrm{L}^{*}$ indicates the darkness or lightness of the colour and, in general, the samples tend to have lighter $\left(\mathrm{L}^{*}\right)$ values above 50 . It was also observed that the samples tended towards red and yellow (i.e., had predominantly positive values of the parameters $\mathrm{a}^{*}$ and $\mathrm{b}^{*}$ ) (Table 1 ).

The predominance of yellow colour in dehydrated bee-pollen after grinding is visually obvious; therefore, the prevalence of positive values of $b^{*}$ was expected. Smaller $b^{*}$ values and higher $\mathrm{a}^{*}$ values in samples heated in the electric oven might be related to the occurrence of reactions during heating with air circulation. Silva, Rosa, and Vilas-Boas (2009) mentioned that heating can cause the oxidation of some compounds such as phenolics.

\subsection{Biological activity indicators}

Phenolic compounds are bioactive substances not synthesized by the human body that have specific metabolic or physiological actions and contribute to disease prevention if regularly present in the diet (Horst \& Lajolo, 2011). Those compounds are secondary metabolites of vegetables whose profiles are species-specific (Campos et al., 2008). In dehydrated bee-pollen, the total phenolic content can vary from 5.4 to $132.4 \mathrm{mg}$ GAE/g (Carpes et al., 2008; Menezes, Maciel, Miranda, \& Druzian, 2010; Morais et al., 2011; Nogueira et al., 2012; Vecchia, Pegaro, Carpes, \& Pegaro, 2009); therefore, the results of this study were consistent with literature. Treatment effects (i.e., the influence of processing) were observed on the phenolic content (Table 2), with the lowest levels observed in the samples treated in an electric oven $(\mathrm{P}<0.05)$. This may be related to the activity of specific enzymes such as polyphenol oxidase and peroxidase. For lyophilization, the samples were frozen when processed, whereas the portions dried in the electric oven had been previously thawed. Freezing and thawing a food matrix can cause cellular damage and therefore the release of enzymes that oxidize phenols (Silva et al., 2009).

As reported in previous studies of the dehydrated bee-pollen samples, the antioxidant capacity determined by DPPH method can vary from 135 to $2.814 \mu \mathrm{mol} \mathrm{TE} / \mathrm{g}$ (Marghitas et al., 2009). The results are usually reported as EC50 (minimum concentration required for of bee-pollen extracts to reduce the initial concentration of the DPPH by 50\%) (Carpes et al., 2008, 2009; Chantarudee et al., 2012), making it difficult to compare studies. Arruda (2013) measured by ORAC method and found values of $133-576 \mu \mathrm{mol} \mathrm{TE} / \mathrm{g}$ of dehydrated beepollen. According to Marghitas et al. (2009), antioxidants compounds respond differently in various measurement methods, therefore it is important to compare different analytical methods involving specific reaction conditions and mechanisms of action.

The antioxidant capacity (by both methods) was higher in lyophilized samples $(\mathrm{P}<0.05)$. An analysis of the coefficients indicated a strong positive correlation between the antioxidant capacity and the total phenolic content (Table 3). The relationship between phenolic content and possible therapeutic properties is controversial for bee-pollen. Pascoal et al. (2014) found no relationship, whereas Carpes et al. (2008) found a positive relationship. It may be that there is a great influence not of the total concentration of these substances in the sample, but the presence of specific phenolic compounds related to botanical origin of bee-pollen.

The inhibition of the hyaluronidase activity was higher $(\mathrm{P}<0.05)$ in the lyophilized samples, therefore it can be inferred that the lyophilized samples have greater anti-inflammatory potential. The inhibition percentages $(7.8 \pm 0.4$ to $17.9 \pm 1.4 \%)$ were lower than those reported for some dehydrated bee-pollen samples 
in another study $(23.6 \pm 2.2$ and $25.2 \pm 3.2 \%)$ (Pascoal et al., 2014), probably also because the botanical origin of the samples were different. Variations among treatments in the antimicrobial capacity according to the microorganism were evident, and indicated higher effectiveness $(\mathrm{P}<0.05)$ in the lyophilized samples.

Antimicrobial capacity against bacteria and yeasts was observed in all the samples, although the bacteria were more sensitive than yeasts. Graikou et al. (2011) analysed dehydrated bee-pollen produced in Greece and also observed a higher resistance of yeasts. Statistical analysis showed a negative correlation between total phenolic content and the antimicrobial capacity of the samples against bacteria (Table 3). It is noteworthy that, although the statistical analysis indicated a negative correlation, the interpretation of this correlation is positive because the lower the MIC, the lower the concentration of dehydrated bee-pollen required to inhibit microbial growth. It can be said that dehydration conditions influence the antimicrobial capacity of the samples only against $E$. coli ATCC, Klebsiella spp, Klebsiella ATCC and C. albicans ATCC. The processing conditions influenced the phenolic content (Table 2) and these compounds were directly related to antimicrobial ability against bacteria (Table 3), therefore it is possible that the lowest antimicrobial potential of the samples dehydrated in an electric oven is related to the lower content of phenolic compounds. Moreover, further studies are required to understand the influence of treatment on the antimicrobial capacity against the yeast.

Correlation analysis indicated a correlation of instrumental colour parameters, phenolic content, antimicrobial capacity against bacteria (excluding E. coli ATCC and Klebsiella ATCC) and antioxidant capacity (Table 3). This is the first study that has established a correlation between the $L^{*} a^{*} b^{*}$ colour parameters with phenolic content and bioactive properties of bee-pollen samples. The instrumental analysis of colour is simple and fast, thus a correlation between this analysis and other characteristics of dehydrated bee-pollen could be used to select samples without a need for complex and time consuming analysis. On the basis of colour, the botanical source of nectar in honey can be distinguished in some cases (Kús et al., 2014).

\subsection{Microbiological quality}

The growth of aerobic mesophilic microorganisms, psychrophiles, molds and yeasts and total coliforms is an indicator of the production conditions, processing, storage and distribution of food (Rocha, 2013). An analysis of these micro-organisms is presented in Table 4 . The results regarding the influence of treatment on these indicators were inconclusive in this study. For the sample collected during April, the largest values of molds and yeasts, total coliforms and aerobic mesophilic microorganisms were observed in the product dried in an electric oven. For the sample collected during
September, the largest values of molds and yeasts and total coliforms were observed in the lyophilized bee-pollen, and there was no significant influence $(P>0.05)$ of the treatments on the growth of aerobic mesophilic microorganisms. It is known that the presence of microorganisms in the bee-pollen is related to contamination of the product while in the hive or during processing (Nogueira et al., 2012). It is possibility that the samples became contaminated after removed from the electric oven or the lyophilizer and before packaging.

Correlation analysis indicated a negative correlation between the phenolic content and total coliforms $(\mathrm{R}=-0790, \mathrm{P}=0.002)$ and the growth of molds and yeasts $(R=-0783, P=0.003)$. Certain phenolics can affect bacterial growth and metabolism according to the concentration in the medium (Pascoal et al., 2014); therefore, it is possible that the values for these micro-organisms would be generally smaller in the samples in which certain phenolics are present or with high phenolic content.

\section{Conclusions}

Lyophilization resulted in higher levels of proteins, lipids, vitamin $\mathrm{E}$ and phenolic compounds, as well an influence on the instrumental colour parameters. Drying in an electric oven had a negative influence on antioxidant, anti-inflammatory and antimicrobial properties, although antimicrobial action is also related to the sensitivity of the microorganism. In general, the use of lyophilization might be a viable alternative to the current process, resulting in dehydrated bee-pollen with higher nutritional and biological properties. The correlation between the colour parameters $\mathrm{L}^{*} \mathrm{a}^{*} \mathrm{~b}^{*}$ and certain biological properties of dehydrated beepollen can facilitate the sample selection for specific experiments. The microbiological quality of the product was not affected by treatment. In future research, a sensory analysis of treated samples under these conditions is recommended to identify whether consumer preference is affected by dehydration process.

\section{Acknowledgements}

The authors are grateful to State of São Paulo Research Foundation (FAPESP) for financial support (FAPESP process 2011/517415) and scholarship granted to AAM De-Melo (FAPESP process 2011/ 11746-8 and FAPESP process 2013/23179-6). For a scholarship granted to OM Barth from the National Counsel of Technological and Scientific Development (CNPq, Process 304067/2013-0). To the MN Própolis company that supplied the samples.

\section{Appendix A.1}

Table 1

Instrumental parameters of colour and nutritive value (dry-matter basis) of bee-pollen samples dehydrated in electric oven and lyophilized.

\begin{tabular}{|c|c|c|c|c|c|}
\hline \multicolumn{2}{|l|}{ Parameters } & \multicolumn{4}{|c|}{ Collection period } \\
\hline & & \multicolumn{2}{|l|}{ April 2012} & \multicolumn{2}{|c|}{ September 2012} \\
\hline & & Electric oven & Lyophilized & Electric oven & Lyophilized \\
\hline \multirow[t]{3}{*}{ Inst. colour } & $\mathrm{L}^{*}(0-100)$ & $51.1 \pm 0.4^{\mathrm{B}}$ & $58.4 \pm 0.4^{\mathrm{A}}$ & $42.8 \pm 1.8^{b}$ & $49.9 \pm 0.5^{a}$ \\
\hline & $a^{*}(-$ or +$)$ & $8.5 \pm 0.1^{\mathrm{A}}$ & $8.4 \pm 0.1^{\mathrm{A}}$ & $11.3 \pm 1.0^{\mathrm{a}}$ & $9.1 \pm 0.2^{\mathrm{b}}$ \\
\hline & $\mathrm{b}^{*}(-$ or +$)$ & $48.1 \pm 0.3^{\mathrm{B}}$ & $56.1 \pm 0.3^{\mathrm{A}}$ & $43.7 \pm 1.9^{\mathrm{b}}$ & $53.7 \pm 0.4^{\mathrm{a}}$ \\
\hline \multicolumn{2}{|c|}{ Proteins (g/100 g) } & $10.7 \pm 0.1^{\mathrm{B}}$ & $11.4 \pm 0.5^{\mathrm{A}}$ & $8.3 \pm 0.1^{\mathrm{b}}$ & $9.6 \pm 0.1^{\mathrm{a}}$ \\
\hline \multicolumn{2}{|c|}{ Lipids (g/100 g) } & $7.6 \pm 0.1^{\mathrm{B}}$ & $8.2 \pm 0.2^{\mathrm{A}}$ & $6.6 \pm 0.3^{b}$ & $7.8 \pm 0.3^{a}$ \\
\hline \multicolumn{2}{|c|}{ Glucose (g/100 g) } & $13.3 \pm 0.8^{\mathrm{A}}$ & $14.9 \pm 0.7^{\mathrm{A}}$ & $18.2 \pm 0.5^{\mathrm{a}}$ & $18.2 \pm 0.2^{\mathrm{a}}$ \\
\hline \multicolumn{2}{|c|}{ Fructose $(\mathrm{g} / 100 \mathrm{~g})$} & $18.7 \pm 1.4^{\mathrm{A}}$ & $21.1 \pm 1.3^{\mathrm{A}}$ & $26.4 \pm 0.7^{\mathrm{a}}$ & $26.9 \pm 0.5^{\mathrm{a}}$ \\
\hline \multirow[t]{4}{*}{ Minerals } & $\mathrm{Ca}(\mathrm{g} / \mathrm{kg})$ & $1.3 \pm 0.0^{\mathrm{A}}$ & $1.2 \pm 0.0^{\mathrm{B}}$ & $1.7 \pm 0.0^{\mathrm{a}}$ & $1.7 \pm 0.0^{\mathrm{a}}$ \\
\hline & $\mathrm{K}(\mathrm{g} / \mathrm{kg})$ & $5.2 \pm 0.1^{\mathrm{A}}$ & $5.2 \pm 0.1^{\mathrm{A}}$ & $2.6 \pm 0.1^{b}$ & $4.2 \pm 0.1^{\mathrm{a}}$ \\
\hline & $\mathrm{Mg}(\mathrm{g} / \mathrm{kg})$ & $0.9 \pm 0.0^{\mathrm{A}}$ & $0.8 \pm 0.0^{\mathrm{B}}$ & $0.5 \pm 0.0^{\mathrm{b}}$ & $0.8 \pm 0.0^{\mathrm{a}}$ \\
\hline & $\mathrm{Na}(\mathrm{mg} / \mathrm{kg})$ & $50.2 \pm 1.0^{\mathrm{A}}$ & $41.3 \pm 1.2^{\mathrm{B}}$ & $32.5 \pm 0.8^{\mathrm{a}}$ & $30.4 \pm 2.0^{\mathrm{a}}$ \\
\hline
\end{tabular}


Table 1 (continued)

\begin{tabular}{|c|c|c|c|c|c|}
\hline \multirow[t]{3}{*}{ Parameters } & & \multicolumn{4}{|c|}{ Collection period } \\
\hline & & \multicolumn{2}{|l|}{ April 2012} & \multicolumn{2}{|c|}{ September 2012} \\
\hline & & Electric oven & Lyophilized & Electric oven & Lyophilized \\
\hline \multirow{10}{*}{ Vitamins } & $\mathrm{Zn}(\mathrm{mg} / \mathrm{kg})$ & $105.8 \pm 3.5^{\mathrm{A}}$ & $103.3 \pm 1.0^{\mathrm{A}}$ & $63.6 \pm 0.6^{\mathrm{b}}$ & $96.2 \pm 3.2^{\mathrm{a}}$ \\
\hline & $\mathrm{Cu}(\mathrm{mg} / \mathrm{kg})$ & $13.3 \pm 0.0^{\mathrm{A}}$ & $13.1 \pm 0.0^{\mathrm{B}}$ & $8.1 \pm 0.6^{\mathrm{b}}$ & $9.8 \pm 0.6^{\mathrm{a}}$ \\
\hline & $\alpha$-tocopherol $(\mu \mathrm{g} / \mathrm{g})$ & $27.5 \pm 0.4^{\mathrm{B}}$ & $37.5 \pm 0.2^{\mathrm{A}}$ & $27.2 \pm 0.3^{\mathrm{b}}$ & $53.7 \pm 3.9^{\mathrm{a}}$ \\
\hline & thiamine (mg/100 g) & $1.3 \pm 0.2^{\mathrm{A}}$ & $0.9 \pm 0.2^{\mathrm{A}}$ & $0.6 \pm 0.0^{\mathrm{a}}$ & $0.5 \pm 0.0^{\mathrm{b}}$ \\
\hline & riboflavin(mg/100 g) & $0.6 \pm 0.0^{\mathrm{A}}$ & $0.4 \pm 0.1^{\mathrm{B}}$ & $0.4 \pm 0.0^{\mathrm{b}}$ & $0.5 \pm 0.0^{\mathrm{a}}$ \\
\hline & $\operatorname{niacin}(\mathrm{mg} / 100 \mathrm{~g})$ & $2.6 \pm 0.1^{\mathrm{A}}$ & $1.5 \pm 0.3^{B}$ & $1.3 \pm 0.0^{\mathrm{a}}$ & $1.3 \pm 0.0^{\mathrm{a}}$ \\
\hline & Niacinamide (mg/100 g) & $3.2 \pm 0.1^{\mathrm{A}}$ & $3.7 \pm 1.0^{\mathrm{A}}$ & $3.0 \pm 0.0^{\mathrm{b}}$ & $3.8 \pm 0.1^{\mathrm{a}}$ \\
\hline & Pyridoxamine (mg/100 g) & $0.6 \pm 0.0^{\mathrm{A}}$ & $0.5 \pm 0.1^{\mathrm{B}}$ & $0.4 \pm 0.0^{\mathrm{b}}$ & $0.5 \pm 0.0^{\mathrm{a}}$ \\
\hline & Pyridoxal $(\mathrm{mg} / 100 \mathrm{~g})$ & $3.8 \pm 0.1^{\mathrm{A}}$ & $3.6 \pm 1.0^{\mathrm{A}}$ & $1.9 \pm 0.0^{\mathrm{b}}$ & $3.4 \pm 0.0^{\mathrm{a}}$ \\
\hline & Pyridoxol (mg/100 g) & $0.2 \pm 0.1^{\mathrm{A}}$ & $0.1 \pm 0.0^{\mathrm{A}}$ & $0.1 \pm 0.0^{\mathrm{b}}$ & $0.2 \pm 0.0^{\mathrm{a}}$ \\
\hline
\end{tabular}

Values correspond to the average \pm standard deviation of three replicates.

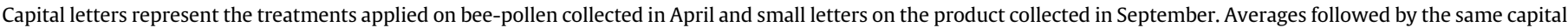
letter or the same small letter are not significantly different $(p>0.05)$.

$\mathrm{PD}(\%)=\left\{1-\left[\mathrm{Abs}_{\text {sample }}-\mathrm{Abs}_{\mathrm{SC}} / \mathrm{Abs}_{\mathrm{control}}\right]\right\} \times 100$

where: Abs sample = absorbance of the sample (dilution analysed;

DPPH solution);

Abs $_{\mathrm{SC}}=$ absorbance of the specific control (dilution analysed; methanol);

$\mathrm{Abs}_{\text {control }}=$ absorbance of the control (metanol; DPPH solution).

\section{Appendix B.1}

Table 2

Total phenolics and pharmacological potential of bee-pollen samples dehydrated in electric oven and lyophilized, in dry-matter basis.

\begin{tabular}{|c|c|c|c|c|c|}
\hline \multirow[t]{3}{*}{ Parameters } & & \multicolumn{4}{|c|}{ Collection period } \\
\hline & & \multicolumn{2}{|l|}{ April 2012} & \multicolumn{2}{|c|}{ September 2012} \\
\hline & & Electric oven & Lyophilized & Electric oven & Lyophilized \\
\hline \multirow{2}{*}{\multicolumn{2}{|c|}{$\begin{array}{l}\text { Total phenolics (mg GAE/g) } \\
\text { Anti-inflammatory capacity (\% inhibition) }\end{array}$}} & $19.7 \pm 0.3^{B}$ & $21.4 \pm 0.1^{\mathrm{A}}$ & $9.2 \pm 0.1^{b}$ & $10.7 \pm 0.1^{\mathrm{a}}$ \\
\hline & & $7.8 \pm 0.4^{\mathrm{B}}$ & $12.6 \pm 1.8^{\mathrm{A}}$ & $13.6 \pm 2.6^{\mathrm{b}}$ & $17.9 \pm 1.4^{\mathrm{a}}$ \\
\hline \multirow[t]{2}{*}{ Antioxidant capacity } & $\mathrm{DPPH}(\mu \mathrm{mol} \mathrm{TE} / \mathrm{g})$ & $63.9 \pm 0.5^{\mathrm{B}}$ & $81.1 \pm 3.7^{\mathrm{A}}$ & $31.7 \pm 0.7^{b}$ & $41.1 \pm 1.0^{\mathrm{a}}$ \\
\hline & ORAC $(\mu \mathrm{mol} \mathrm{TE} / \mathrm{g})$ & $481.3 \pm 6.1^{\mathrm{B}}$ & $559.3 \pm 18.3^{\mathrm{A}}$ & $310.1 \pm 10.3^{b}$ & $367.8 \pm 11.3^{\mathrm{a}}$ \\
\hline \multirow[t]{10}{*}{ Antimicrobial capacity ${ }^{1}(\mathrm{MIC})^{2}$} & Sp ESA12 & $3.5 \pm 0.8^{\mathrm{A}}$ & $2.5 \pm 0.5^{\mathrm{A}}$ & $4.8 \pm 0.7^{\mathrm{a}}$ & $4.0 \pm 0.7^{\mathrm{a}}$ \\
\hline & Sp ATCC & $2.9 \pm 0.7^{\mathrm{A}}$ & $2.1 \pm 0.1^{\mathrm{A}}$ & $4.2 \pm 0.6^{\mathrm{a}}$ & $2.7 \pm 0.5^{b}$ \\
\hline & Sa ESA54 & $3.8 \pm 0.6^{\mathrm{A}}$ & $3.1 \pm 0.3^{\mathrm{A}}$ & $6.1 \pm 1.0^{\mathrm{a}}$ & $4.0 \pm 0.8^{b}$ \\
\hline & Sa ATCC & $3.2 \pm 0.6^{\mathrm{A}}$ & $2.3 \pm 0.3^{\mathrm{A}}$ & $4.0 \pm 0.5^{\mathrm{a}}$ & $3.2 \pm 0.6^{\mathrm{a}}$ \\
\hline & Ec ESA72 & $5.8 \pm 0.8^{\mathrm{A}}$ & $4.6 \pm 0.4^{\mathrm{A}}$ & $6.8 \pm 0.7^{a}$ & $5.5 \pm 0.7^{\mathrm{a}}$ \\
\hline & Ec ATCC & $4.3 \pm 0.5^{\mathrm{A}}$ & $3.5 \pm 0.2^{\mathrm{B}}$ & $4.7 \pm 0.5^{\mathrm{a}}$ & $4.0 \pm 0.2^{b}$ \\
\hline & $K$ spp & $6.2 \pm 0.9^{\mathrm{A}}$ & $4.5 \pm 0.6^{B}$ & $7.1 \pm 0.7^{\mathrm{a}}$ & $5.7 \pm 0.6^{b}$ \\
\hline & $K$ ATCC & $5.9 \pm 0.8^{\mathrm{A}}$ & $3.4 \pm 1.0^{\mathrm{B}}$ & $6.5 \pm 0.7^{\mathrm{a}}$ & $4.8 \pm 0.6^{b}$ \\
\hline & Ca ESA109 & $25.3 \pm 2.5^{\mathrm{A}}$ & $22.1 \pm 2.6^{\mathrm{A}}$ & $27.2 \pm 4.0^{\mathrm{a}}$ & $21.9 \pm 4.0^{\mathrm{a}}$ \\
\hline & Ca ATCC & $22.6 \pm 0.9^{\mathrm{A}}$ & $18.8 \pm 0.9^{\mathrm{B}}$ & $22.8 \pm 1.5^{\mathrm{a}}$ & $17.9 \pm 0.5^{\mathrm{b}}$ \\
\hline
\end{tabular}

Values correspond to the average \pm standard deviation of three replicates.

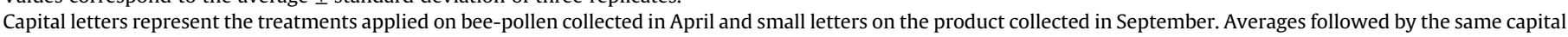
letter or the same small letter are not significantly different $(p>0.05)$.

${ }^{1}$ Sp: Streptococcus pyogenes; Sa: Staphylococcus aureus; Ec: Escherichia coli; K: Klebsiella; Ca: Candida albicans.

${ }^{2}$ MIC: minimum inhibitory concentration (the lowest concentration of dehydrated bee-pollen extract that inhibited visible growth of microorganisms).

\section{Appendix C.1}

Table 3

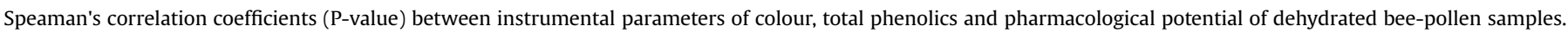

\begin{tabular}{|c|c|c|c|c|c|c|c|}
\hline & Ins. colour $\mathrm{L}^{*}$ & Ins. colour $\mathrm{a}^{*}$ & Ins. colour $\mathrm{b}^{*}$ & Phenolics & $\mathrm{DPPH}$ & ORAC & Hyal. Inhibition \\
\hline Ins. colour $\mathrm{L}^{*}$ & 1 & & & & & & \\
\hline Ins. colour a* & $\begin{array}{l}-0.958 \\
P<0.001\end{array}$ & 1 & & & & & \\
\hline Ins. colour b* & $\begin{array}{l}0.741 \\
P=0.006\end{array}$ & $\begin{array}{l}-0.629 \\
P=0.028\end{array}$ & 1 & & & & \\
\hline Phenolics & $\begin{array}{l}0.972 \\
P<0.001\end{array}$ & $\begin{array}{l}-0.902 \\
P<0.001\end{array}$ & $\begin{array}{l}0.727 \\
P=0.007\end{array}$ & 1 & & & \\
\hline
\end{tabular}


Table 3 (continued)

\begin{tabular}{|c|c|c|c|c|c|c|c|}
\hline & Ins. colour $\mathrm{L}^{*}$ & Ins. colour a* & Ins. colour b* & Phenolics & DPPH & ORAC & Hyal. Inhibition \\
\hline \multirow[t]{2}{*}{ DPPH } & 0.951 & -0.930 & 0.727 & 0.958 & 1 & & \\
\hline & $\mathrm{P}<0.001$ & $\mathrm{P}<0.001$ & $P=007$ & $\mathrm{P}<0.001$ & & & \\
\hline \multirow[t]{2}{*}{ ORAC } & 0.944 & -0.930 & 0.755 & 0.916 & 0.958 & 1 & \\
\hline & $\mathrm{P}<0.001$ & $\mathrm{P}<0.001$ & $P=0.005$ & $\mathrm{P}<0.001$ & $\mathrm{P}<0.001$ & & \\
\hline \multirow[t]{2}{*}{ Hyal. inhibition } & -0.315 & 0.371 & 0.259 & -0.371 & -0.308 & -0.301 & 1 \\
\hline & $\mathrm{P}=0.319$ & $\mathrm{P}=0.236$ & $\mathrm{P}=0.417$ & $\mathrm{P}=0.236$ & $P=0.331$ & $\mathrm{P}=0.342$ & \\
\hline \multirow[t]{2}{*}{ Sp ESA12 } & -0.811 & 0.727 & -0.734 & -0.818 & -0.783 & -0.762 & 0.266 \\
\hline & $P=0.001$ & $P=0.007$ & $P=0.007$ & $\mathrm{P}=0.001$ & $P=0.003$ & $\mathrm{P}=0.004$ & $\mathrm{P}=0.404$ \\
\hline \multirow{2}{*}{ Sp ATCC } & -0.774 & 0.690 & -0.823 & -0.767 & -0.697 & -0.774 & -0.032 \\
\hline & $P=0.003$ & $\mathrm{P}=0.013$ & $\mathrm{P}=0.001$ & $\mathrm{P}=0.004$ & $P=0.012$ & $P=0.003$ & $\mathrm{P}=0.923$ \\
\hline \multirow[t]{2}{*}{ Sa ESA54 } & -0.839 & 0.846 & -0.720 & -0.825 & -0.846 & -0.748 & 0.049 \\
\hline & $P=0.001$ & $P=0.001$ & $P=0.008$ & $P=0.001$ & $P=0.001$ & $P=0.005$ & $P=0.880$ \\
\hline \multirow[t]{2}{*}{ Sa ATCC } & -0.755 & 0.699 & -0.587 & -0.762 & -0.727 & -0.573 & 0.049 \\
\hline & $\mathrm{P}=0.005$ & $\mathrm{P}=0.011$ & $\mathrm{P}=0.045$ & $\mathrm{P}=0.004$ & $P=0.007$ & $\mathrm{P}=0.051$ & $\mathrm{P}=0.880$ \\
\hline \multirow{2}{*}{ Ec ESA72 } & -0.727 & 0.594 & -0.769 & -0.762 & -0.664 & -0.643 & 0.070 \\
\hline & $P=0.007$ & $\mathrm{P}=0.042$ & $\mathrm{P}=0.003$ & $\mathrm{P}=0.004$ & $P=0.018$ & $\mathrm{P}=0.024$ & $\mathrm{P}=0.829$ \\
\hline \multirow[t]{2}{*}{ Ec ATCC } & -0.552 & 0.413 & -0.825 & -0.587 & -0.490 & -0.580 & -0.098 \\
\hline & $\mathrm{P}=0.063$ & $\mathrm{P}=0.183$ & $\mathrm{P}=0.001$ & $\mathrm{P}=0.045$ & $P=0.106$ & $P=0.048$ & $\mathrm{P}=0.762$ \\
\hline \multirow[t]{2}{*}{$K$ spp } & -0.643 & 0.636 & -0.783 & -0.643 & -0.699 & -0.720 & -0.070 \\
\hline & $\mathrm{P}=0.024$ & $\mathrm{P}=0.026$ & $\mathrm{P}=0.003$ & $\mathrm{P}=0.024$ & $P=0.011$ & $\mathrm{P}=0.008$ & $\mathrm{P}=0.829$ \\
\hline \multirow[t]{2}{*}{$K$ ATCC } & -0.594 & 0.441 & -0.916 & -0.636 & -0.587 & -0.643 & -0.196 \\
\hline & $\mathrm{P}=0.042$ & $\mathrm{P}=0.152$ & $\mathrm{P}<0.001$ & $\mathrm{P}=0.026$ & $P=0.045$ & $\mathrm{P}=0.024$ & $\mathrm{P}=0.542$ \\
\hline \multirow[t]{2}{*}{ Ca ESA109 } & -0.392 & 0.252 & -0.573 & -0.476 & -0.357 & -0.308 & -0.196 \\
\hline & $\mathrm{P}=0.208$ & $\mathrm{P}=0.430$ & $\mathrm{P}=0.051$ & $\mathrm{P}=0.118$ & $\mathrm{P}=0.255$ & $\mathrm{P}=0.331$ & $\mathrm{P}=0.542$ \\
\hline \multirow[t]{2}{*}{ Ca ATCC } & -0.287 & 0.217 & -0.750 & -0.273 & -0.221 & -0.249 & -0.543 \\
\hline & $P=0.365$ & $\mathrm{P}=0.498$ & $\mathrm{P}=0.005$ & $P=0.390$ & $P=0.491$ & $P=0.436$ & $P=0.068$ \\
\hline
\end{tabular}

Sp: Streptococcus pyogenes; Sa: Staphylococcus aureus; Ec: Escherichia coli; K: Klebsiella; Ca: Candida albicans.

Significance level $(\alpha)$ of 0.05 .

\section{Appendix D.1}

Table 4

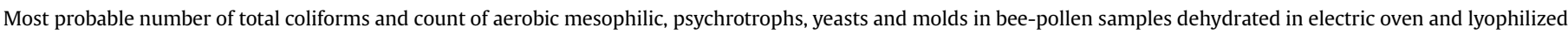

\begin{tabular}{|c|c|c|c|c|}
\hline \multirow[t]{3}{*}{ Microorganism } & \multicolumn{4}{|c|}{ Collection period } \\
\hline & \multicolumn{2}{|l|}{ April 2012} & \multicolumn{2}{|c|}{ September 2012} \\
\hline & Electric oven & Lyophilized & Electric oven & Lyophilized \\
\hline Total coliforms (MPN/g) & $47 \pm 17^{\mathrm{A}}$ & $13 \pm 5^{\mathrm{B}}$ & $123 \pm 25^{b}$ & $285 \pm 61^{a}$ \\
\hline Aerobic mesophilic (CFU/g) & $17 \pm 8^{A}$ & $<10^{\mathrm{B}}$ & $<10^{\mathrm{a}}$ & $<10^{\mathrm{a}}$ \\
\hline Psychotrophs (CFU/g) & $<10^{\mathrm{A}}$ & $<10^{\mathrm{A}}$ & $<10^{\mathrm{a}}$ & $<10^{\mathrm{a}}$ \\
\hline Yeasts and molds (CFU/g) & $99 \pm 31^{\mathrm{A}}$ & $16 \pm 5^{\mathrm{B}}$ & $242 \pm 52^{\mathrm{b}}$ & $935 \pm 233^{a}$ \\
\hline
\end{tabular}

Values correspond to the average \pm standard deviation of three replicates.

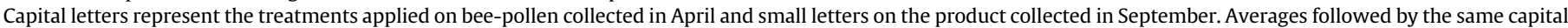
letter or the same small letter are not significantly different $(\mathrm{p}>0.05)$.

\section{References}

A.O.A.C. (2000). Official methods of analysis of the association of official analytical chemists (17th ed.). Gaithersburg.

Almeida-Muradian, L. B., Arruda, V. A. S., \& Barreto, L. M. R. C. (2012). Manual de Controle de Qualidade do Pólen Apícola. São Paulo: APACAME.

Arruda, V. A. S. (2013). Pólen apícola desidratado: composição físico-química, qualidade microbiologica, compostos fenólicos e flavonoides, atividade antioxidante e origem botânica (Doctor's thesis). Retrieved from http://www.teses.usp.br/ teses/disponiveis/9/9131/tde-22062015-172352/es.php Accessed 30.08.15.

Arruda, V. A. S., Santos-Pereira, A. A., Freitas, A. S., Barth, O. M., \& AlmeidaMuradian, L. B. (2013). Dried bee pollen: B complex vitamins, physicochemical and botanical composition. Journal of Food Composition and Analysis, 29(2), $100-105$.

Barreto, L. M. R. C., Funari, S. R. C., \& Orsi, R. O. (2005). Pólen apícola: perfil da produção no Brasil. Congresso de Apicultura del Mercosur. Retrieved from http://pt.scribd.com/doc/23836092/14-polen-apicola-brasil\#scribd Accessed 24.01.15.

Barth, O. M., Freitas, A. S., Oliveira, E. S., Silva, R. A., Maester, F. M., Andrella, R. R. S., et al. (2010). Evaluation of the botanical origin of commercial dry bee pollen load batches using pollen analysis: a proposal for technical standardization. Anais da Academia Brasileira de Ciências, 82(4), 893-902.
Bogdanov, S. (2012). The bee pollen book: Chapter 1. Retrieved from www.beehexagon.net Accessed 22.06.15.

Brand-Williams, W., Cuvelier, M. E., \& Berset, C. (1995). Use of a free radical method to evaluate antioxidant. Food Science and Technology, 28(1), 25-30.

Brasil. (2001). Instrução Normativa $n^{\circ}$ 3, de 19 de janeiro de 2001 que aprova os regulamentos técnicos de identidade e qualidade de apitoxina, cera de abelha, geléia real, geléia real liofilizada, pólen apícola, própolis e extrato de própolis. Retrieved from http://sistemasweb.agricultura.gov.br/sislegis/action/detalhaAto.do? method=consultarLegislacaoFederal Accessed 24.01.15.

Campos, M. G. R., Bogdanov, S., Almeida-Muradian, L. B., Szczesna, T., Mancebo, Y., Frigerio, C., et al. (2008). Pollen composition and standardization of analytical methods. Journal of Apicultural Research and Bee World, 47, 156-163.

Carpes, S. T., Mourão, G. B., Alencar, S. M., \& Masson, M. L. (2009). Chemical composition and free radical scavenging activity of Apis mellifera bee pollen from Southern Brazil. Brazilian Journal of Food Technology, 12(3), 220-229.

Carpes, S. T., Prado, A., Moreno, I. A. M., Mourão, G. B., Alencar, S. M., \& Masson, M. L. (2008). Avaliação do potencial antioxidante do pólen apícola produzido na Região Sul do Brasil. Química Nova, 31(7), 1660-1664.

Chantarudee, A., Phuwapraisirisan, P., Kimura, K., Okuyama, M., Mori, H., Kimura, A. et al. (2012). Chemical constituents and free radical scavenging activity of corn pollen collected from Apis mellifera hives compared to floral corn pollen at Nan, Thailand. BMC Complementary and Alternative Medicine, 12(45), 1-12. 
Domínguez-Valhondo, D., Gil, D. B., Hernandez, M. T., \& Gonzalez-Gomez, D. (2011) Influence of the commercial processing and floral origin on bioactive and nutritional properties of honeybee-collected pollen. International Journal of Food Science and Technology, 46(10), 2204-2211.

Franco, B. D. G. M., \& Landgraf, M. (2009). Microbiologia dos Alimentos (6th ed.). São Paulo: Atheneu.

Funari, S. R. C., Rocha, H. C., Sforcin, J. M., Filho, H. G., Curi, P. R., GomesDierckx, S. M. A., et al. (2003). Composições bromatológica e mineral do pólen coletado por abelhas africanizadas (Apis mellifera L.) em Botucatu, Estado de São Paulo. Archivos Latinoamericanos de Produccion Animal, 11, 88-93.

Graikou, K., Kapeta, S., Aligiannis, N., Sotiroudis, G., Chondrogianni, N., Gonos, E., et al. (2011). Chemical analysis of Greek pollen - antioxidant, antimicrobial and proteasome activation properties. Chemistry Central Journal, 5(33), 1-9.

Horst, M. A., \& Lajolo, F. M. (2011). Biodisponibilidade de compostos bioativos de alimentos. 2011. Retrieved from www.fcf.usp.br Accessed 02.04.11.

Huang, D., Ou, B., \& Prior, R. L. (2005). The chemistry behind antioxidant capacity assays. Journal of Agricultural and Food Chemistry, 53(6), 1841-1856.

Human, H., \& Nicolson, S. W. (2006). Nutritional content of fresh, bee-collected and stored pollen of Aloe greatheadii var. davyana (Asphodelaceae). Phytochemistry, 67(14), 1486-1492.

IPQ. (1985). Carnes e produtos cárneos. Contagem de Bolores e Leveduras: NP 2077. Costa de Caparica.

IPQ. (1987). Microbiologia alimentar. Regras gerais para a contagem de microorganismos psicrotróficos: NP 2307. Costa de Caparica.

IPQ. (2002). Microbiologia alimentar. Regras gerais para a contagem de microorganismos a $30^{\circ} \mathrm{C}$ : NP 3788. Costa de Caparica.

Kús, P. M., Congiu, F., Teper, D., Sroka, Z., Jerkovic, I., \& Tuberoso, C. I. G. (2014). Antioxidant activity, color characteristics, total phenol content and genera HPLC fingerprints of six Polish unifloral honey types. LWT - Food Science and Technology, 55(1), 124-130.

Lee, Y. P., Kim, S. H., Bang, J. W., Lee, H. S., Kwak, S. S., \& Kwon, S. Y. (2007). Enhanced tolerance to oxidative stress in transgenic tobacco plants expressing three antioxidant enzymes in chloroplasts. Plant Cell Reports, 26(5), 591-598.

Malavolta, E., Vitti, G. C., \& Oliveira, S. A. (1989). Avaliação do estado nutricional das plantas: Princípios e aplicações. Piracicaba: Associação Brasileira para Pesquisa da Potassa e do Fosfato.

Marghitas, L. A., Stanciu, O. G., Dezmirean, D. S., Bobis, O., Popescu, O., Bogdanov, S. et al. (2009). In vitro antioxidant capacity of honeybee-collected pollen of selected floral origin harvested from Romania. Food Chemistry, 115(3), 878-883.

Medeiros, K. C. P., Figueiredo, C. A. V., Figueredo, T. B., Freire, K. R. L., Santos, F. A. R. Alcantara-Neves, N. M., et al. (2008). Anti-allergic effect of bee pollen phenolic extract and myricetin in ovalbumin-sensitized mice. Journal of Ethnopharmacology, 119(1), 41-46.

Melo, I. L. P., \& Almeida-Muradian, L. B. (2010). Stability of antioxidants vitamins in bee pollen samples. Química Nova, 33(3), 514-518.

Menezes, J. D. S., Maciel, L. F., Miranda, M. S., \& Druzian, J. I. (2010). Compostos bioativos e potencial antioxidante do pólen apícola produzido por abelhas africanizadas (Apis mellifera L.). Revista do Instituto Adolfo Lutz, 69(2), 233-242.

Mensor, L. L., Menezes, F. S., Leitão, G. G., Reis, A. S., Santos, T. C., Coube, C. S., et al. (2001). Screening of Brazilian plant extracts for antioxidant activity by the use of DPPH free radical method. Phytotheraphy Research, 15(2), 127-130.

Miquel, E., Alegría, A., Barberá, R., Farré, R., \& Clemente, G. (2004). Stability of tocopherols in adapted milk-based infant formulas during storage. International Dairy Journal, 14(11), 1003-1011.

Morais, M., Moreira, L., Feás, X., \& Estevinho, L. M. (2011). Honeybee-collected pollen from five Portuguese natural parks: palynological origin, phenolic content, antioxidant properties and antimicrobial activity. Food and Chemical Toxicology, 49(5), 1096-1101.
Morgano, M. A., Martins, M. C. T., Rabonato, L. C., Milani, R. F., Yotsuyanagi, K., \& Rodriguez-Amaya, D. B. (2012). A comprehensive investigation of the mineral composition of brazilian bee pollen: geographic and seasonal variations and contribution to human diet. Journal of the Brazilian Chemical Society, 23(4), 727-736.

Nogueira, C., Iglesias, A., Feás, X., \& Estevinho, L. M. (2012). Commercial bee pollen with different geographical origins: a comprehensive approach. International Journal of Molecular Sciences, 13(9), 11173-11187.

Oliveira, K. C. L. S., Moriya, M., Azedo, R. A. B., Almeida-Muradian, L. B. Teixeira, E. W., Alves, M. L. T. M. F., et al. (2009). Relationship between botanical origin and antioxidants vitamins of bee-collected pollen. Química Nova, 32(5), 1099-1102.

Ou, B., Hampsch-Woodill, M., \& Prior, R. L. (2001). Development and validation of an improved oxygen radical absorbance capacity assay using fluorescein as the fluorescent probe. Journal of Agricultural and Food Chemistry, 49(10), 4619-4626.

Paramás, A. M. G., Bárez, J. A. G., Marcos, C. C., García-Villanova, R. J., \& Sánchez, J. S. (2006). HPLC-fluorimetric method for analysis of amino acids in products of the hive (honey and bee-pollen). Food Chemistry, 95(1), 148-156.

Pascoal, A., Rodrigues, S., Teixeira, A., Feás, X., \& Estevinho, L. M. (2014). Biological activities of commercial bee pollens: antimicrobial, antimutagenic, antioxidant and anti-inflammatory. Food and Chemical Toxicology, 63, 233-239.

Qian, W. L., Khan, Z., Watson, D. G., \& Fearnley, J. (2008). Analysis of sugars in bee pollen and propolis by ligand exchange chromatography in combination with pulsed amperometric detection and mass spectrometry. Journal of Food Composition and Analysis, 21, 78-83.

Rocha, J. F. M. (2013). Avaliação do efeito do armazenamento na qualidade do pólen apícola (Master's thesis). Retrieved from http://hdl.handle.net/10198/9289 Accessed 24.01.15 Accessed 26.01.15.

Sattler, J. A. G. (2013). Quantificação das vitaminas antioxidantes $E(\alpha-, \beta-, \gamma-, \delta$ tocoferol), $C$ (ácido ascórbico), pró-vitamina $A(\alpha-, \beta$-Caroteno) e composição química do pólen apícola desidratado produzido em apiários georreferenciados da região Sul do Brasil (Master's thesis). Retrieved from http://www.teses.usp.br/ teses/disponiveis/9/9131/tde-18032014-151137/es.php Accessed 28.06.15.

Silva, J. C., Rodrigues, S., Feás, X., \& Estevinho, L. M. (2012). Antimicrobial activity, phenolic profile and role in the inflammation of propolis. Food and Chemical Toxicology, 50(5), 1790-1795.

Silva, M. V., Rosa, C. I. L. F., \& Vilas-Boas, E. V. B. (2009). Conceitos e métodos de controle do escurecimento enzimático no processamento mínimo de frutas e hortaliças. Boletim CEPPA, 27, 83-96.

Souza, B. R. (2014). Quantification of $B$ complex vitamins $\left(B_{1}, B_{2}\right)$ and vitamers of vitamins $B_{3}$ and $B_{6}$ in dehydrated bee pollen samples from Southern Brazil (Master's thesis). Retrieved from http://www.teses.usp.br/teses/disponiveis/9/9131/tde27052015-141055/pt-br.php Accessed 28.08.15.

Sucupira, N. R., Xerez, A. C. P., \& Souza, P. H. M. (2012). Perdas vitamínicas durante o tratamento térmico dos alimentos. Científica: ciências biológicas e da saúde, 14(2), 121-128.

USDA - United States Department of Agriculture. (1998). Dietary reference intakes for thiamin, riboflavin, niacin, vitamin B6, folate, vitamin B12, pantothenic acid, biotin, and choline. Retrieved from http://www.nal.usda.gov/fnic/DRI//DRI_Thiamin/ thiamin full report.pdf Accessed 15.05.15.

Vecchia, P. D., Pegaro, B., Carpes, S. T., \& Pegaro, A. (2009). Determinação de compostos fenólicos e flavonóides em pólen apícola coletado em Mandirituba-PR. Seminário de Iniciação Científica e Tecnológica. Retrieved from www.utfpr.edu. br Accessed 13.03.13.

Yang, K., Wu, D., Ye, X., Liu, D., Chen, J., \& Sun, P. (2013). Characterization of chemical composition of bee pollen in China. Journal of Agricultural and Food Chemistry, 61(3), 708-718. 